\title{
Effect of the fuel type on the performance of an externally fired micro gas turbine cycle
}

3 Fabiola Baina ${ }^{a, b, *}, 1$, Anders Malmquist ${ }^{a, 2}$, Lucio Alejo ${ }^{b, 1}$, Torsten H. Fransson ${ }^{a, 3}$

a Department of Energy Technology, School of Industrial Technology and Management (ITM), Royal Institute of Technology (KTH), 10044 Stockholm Sweden

${ }^{\mathrm{b}}$ Facultad de Ciencias y Tecnología (FCyT), Universidad Mayor de San Simón (UMSS), Cochabamba, Bolivia

*Corresponding author at: Department of Energy Technology, School of Industrial Technology and Management (ITM), Royal Institute of Technology (KTH), 10044 Stockholm Sweden. Tel.: +46879074 42; fax: +468204161

E-mail addresses: fabiola@kth.se (F. Baina), andmal@kth.se (A. Malmquist) lalejo@fcyt.umss.edu.bo (L. Alejo),fransson@energy.kth.se (T.H. Fransson).

${ }^{1}$ Tel.: +59142336 48; fax: +5914232548.

${ }^{2}$ Tel.: +468 79074 38; fax: +468204161.

${ }^{3}$ Tel.: +468 79074 75; fax: +468204161.

\section{Abstract}

Externally fired gas turbines open the possibility of using fuels of lower quality than conventional gas turbines and internal combustion engines. This is because in externally fired gas turbines, the flue gases heat the compressed air in a high temperature heat exchanger. This heat exchanger can more easily deal with contaminants present in the flue gases. In this regard, the configuration of externally fired gas turbines represents an interesting option for biomass gasification gas. The contaminants and low heating value (LHV) of this fuel have made it difficult to find a conversion technology for heat and power generation. For this reason, it is important to study the influence of biomass derived gas as fuel on the performance of this system and consider the effects of the contaminants in the 
high temperature heat exchanger. This is studied in this work through simulations using Aspen Plus and Matlab. The test data of an externally fired micro gas turbine prototype was used to validate the simulation. The fuel considered was biomass gasification gas with varying concentrations of benzene 100,10 and $1 \mathrm{~g} / \mathrm{Nm}^{3}$ (hereafter named $\mathrm{m} 100, \mathrm{~m} 10$, and $\mathrm{m} 1$ respectively). Additionally, mixtures of biomass derived gas and methane were studied for 10 and $50 \%$ of the thermal power of the combustor. The fuel inlet temperature to the combustor varied from $150^{\circ} \mathrm{C}$ to $750^{\circ} \mathrm{C}$ in order to represent the fuel gas after removal of particles by a cyclone and a filter. The results showed that the electrical power output increases when high fuel inlet temperatures to the combustor are used. Additionally, although it would be expected that fuels with higher LHV (lower heating value) show higher temperatures and higher output power, this does not always occur because of the composition of the fuels and their respective flue gas temperatures. The addition of methane does not have a large effect on the electrical power output. For a fixed temperature limit in the heat exchanger, the composition of the fuels does not play an important role. However, high fuel inlet temperatures to the combustor show slightly higher efficiencies. Additionally, the effect on the electrical power output of increasing the pressure drop as a result of increased thickness of deposit materials in the heat exchanger was analyzed.

Keywords: Externally fired gas turbine; biomass derived gas; electrical power output; fuel inlet temperature; lower heating value; flue gas temperature; pressure drop.

\section{Nomenclature}

$A F_{\text {stoic hiometric }}$ Stoichiometric air to fuel ratio, dimensionless

$C p_{\text {air } 1-2} \quad$ Average specific heat capacity, $\mathrm{J} / \mathrm{kgK}$

$C p_{\text {air 3-4 }} \quad$ Average specific heat capacity, $\mathrm{J} / \mathrm{kgK}$

$C p_{\text {water }} \quad$ Average specific heat capacity, $\mathrm{J} / \mathrm{kgK}$

$k \quad$ Thermal conductivity, $\mathrm{W} / \mathrm{mK}$

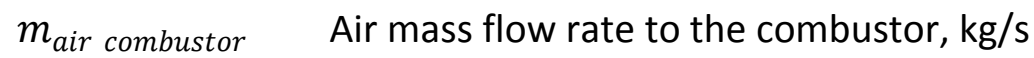

$m_{\text {air stoic hiometric }}$ Theoretical air mass flow rate to the combustor, $\mathrm{kg} / \mathrm{s}$ 
58

$m_{\text {fuel }}$

59

$n_{\text {generator }}$

60

$$
n_{m e c}
$$

$61 n_{S C}$

$62 n_{S T}$

$63 \eta_{C H P}$

$64 P$

$65 \Delta P$

$66 P_{C}$

$67 \quad P_{e l}$

$68 P_{T}$

$69 \quad P_{t h}$

$70 \quad \mathrm{~T}$

$71 T_{w, \text { in }}$

$72 T_{w, \text { out }}$

$73 U$

$74 \quad$ Greek letters

$75 \gamma$

76

\section{Subscripts}

$77 \quad 1$

Air inlet to the compressor
Water mass flow rate, $\mathrm{kg} / \mathrm{s}$

Air mass flow rate to the compressor, $\mathrm{kg} / \mathrm{s}$

Fuel mass flow rate, $\mathrm{kg} / \mathrm{s}$

Generator efficiency, dimensionless

Mechanical efficiency, dimensionless

Isentropic compressor efficiency, dimensionless

Isentropic turbine efficiency, dimensionless

Overall efficiency, dimensionless

Pressure, $\mathrm{Pa}$

Pressure drop, $\mathrm{Pa}$

Compressor power, Watts

Electrical power output, Watts

Turbine power output, Watts

Thermal power output, Watts

Temperature, $\mathrm{K}$

Water inlet temperature, $\mathrm{K}$

Water outlet temperature, $\mathrm{K}$

Overall heat transfer coefficient, $\mathrm{W} / \mathrm{m}^{2} \mathrm{~K}$

Heat capacity ratio, dimensionless 
Air outlet from the heat exchanger

Exhaust air from the turbine

\section{Abbreviations}

Externally fired gas turbine

$87 \quad$ IGCC

Integrated gasification combined cycle

88 LHV

Lower heating value, $\mathrm{MJ} / \mathrm{kg}$

89 TIT

Turbine inlet temperature, $\mathrm{K}$

\section{Introduction}

Biomass gasification gas is a combustible gas mainly composed of $\mathrm{H}_{2}, \mathrm{CO}, \mathrm{CH}_{4}, \mathrm{CO}_{2}, \mathrm{~N}_{2}, \mathrm{H}_{2} \mathrm{O}$, and light hydrocarbons. It also contains tar, dust, particulates, alkali metals, ammonia and other compounds that are known as contaminants [1]. The composition of biomass gasification gas varies depending on the biomass feedstock, the type of gasifier, and the operating conditions [2].

There are advantages and disadvantages in the use of biomass gasification gas. The main advantages are its versatility and easy control of the combustion process. For instance,

100 emissions from biomass derived gas can be controlled more easily than combustion of solid biomass [3]. The main disadvantages are the contaminants in the gasification gas and the 
lower heating value (LHV). The contaminants in biomass derived gas can cause erosion, corrosion, and fouling in the surfaces in contact with the gas [4]. Additionally, the gas produced from gasification has a lower heating value (LHV) that can be one tenth of that of natural gas [2].

The characteristics of biomass derived gas have made it difficult to find a conversion technology capable to deal with this fuel. Steam turbines commonly use low quality fuels such as biomass derived gas. These systems are suitable for large scales (MW ranges). However, for small scales the water-steam technology is complex and costly [5]. Moreover, at small scales, other technologies such as internal combustion engines and gas turbines offer higher efficiencies [6]. Gas turbines and internal combustion engines are known to require fuels with very low or no concentrations of tar, alkali metals and particulates. These components can cause abrasion and fouling in the blades of gas turbines and nozzle of internal combustion engines [2]. In order to fulfill these requirements, cleaning methods are needed after gasification. However, the addition of these steps make these systems costly and complex [7].

At small scales, energy conversion technologies with less strict fuel quality requirements than conventional gas turbines and internal combustion engines are interesting for biomass gasification gas. In this regard, externally fired gas turbines integrated with a biomass gasifier can be an option since in such systems the flue gases are not in contact with the turbine [7]. This makes externally fired gas turbines a fuel flexible system [5].

Externally fired gas turbines are mainly composed of a compressor, a turbine, a high temperature heat exchanger, and a combustor. The configuration is such that compressed air enters the high temperature heat exchanger where heat from the flue gases is transferred to the air. Later, this hot compressed air expands in the turbine.

The heat exchanger is then the more critical component of the cycle. The heat exchanger is expected to be able to deal with dirty fuels more easily than the turbine itself [5]. It should be able to stand high temperatures for long periods of time and handle the flue gases from biomass gasification gas [8]. Additionally, several parameters can affect its performance such as the geometry, material and the hot and cold side fluid characteristics. 
131 The integration of externally fired gas turbines with biomass gasification gas has been studied by some authors. Al-attab and Zainal [9] developed a small scale externally fired micro gas turbine (about $5 \mathrm{kWe}$ ) coupled to a biomass gasifier. The overall efficiency of the system was about $30 \%$. Recovery of heat from the hot flue gases was suggested to increase the overall efficiency.

Vera et al. [10] modeled a $70 \mathrm{~kW}_{\mathrm{e}}$ and $160 \mathrm{~kW}_{\text {th }}$ externally fired gas turbine coupled to a downdraft gasifier (gasifier-EFGT). An overall and an electrical efficiency of $64 \%$ and $20 \%$ were reported respectively. A trade-off between the heat exchanger area and the electrical efficiency was carried out. Additionally, the gasifier-EFGT cycle was also compared with an integrated gasification combined cycle (IGCC) plant. Both with an electrical power output of $70 \mathrm{~kW}_{\mathrm{e}}$. It was found that the electrical and overall efficiency of the gasifier-EFGT was higher than that of the IGCC system.

Datta et al. [11] evaluated the influence of the pressure ratio, turbine inlet temperature (TIT), and cold end temperature difference (CETD) of the heat exchanger on the thermal efficiency of a $100 \mathrm{~kW}$ externally fired gas turbine [11]. Optimum operating conditions were found for high thermal efficiencies and for a specific air flow through the turbine. Based on the effects of these parameters, three different sets of operating conditions were studied for this system. A trade-off in the operating parameters was carried out for a $100 \mathrm{~kW}$ externally fired gas turbine [11].

Soltani et al. [12] studied an externally fired gas turbine system in the range of $1 \mathrm{MW}$ integrated with a gasifier using an advanced exergy analysis. The results showed that the interaction between the constituents was not strong for the system proposed. Additionally, it was suggested that improving the efficiency of the heat exchanger can improve the performance of the system although higher exergy destruction was reported for the combustor and gasifier [12].

Arena et al. [7] compared technically and economically a gasifier-internal combustion engine and a gasifier-externally fired gas turbine both for a plant capacity of $200 \mathrm{kWe}$. Higher reliability and internal rate of return was offered by the first option. However, the authors indicated that decrease in costs due to increased installations of EFGT systems could make this system competitive in the future. 
Cordiner and Mulone [13] evaluated the performance of an externally fired gas turbine based demonstration plant of about $70 \mathrm{kWe}$ using wood as feedstock. A model of this plant was developed in order to investigate the effect of the fuel characteristics on the performance of the plant. The results showed an electrical efficiency of $13 \%$ when using dry pinecone. An almost linear increase of power output and electrical efficiency was found with increasing the higher heating value of biomass and the turbine inlet temperature [13]. A dual combustion system was proposed by Riccio and Chiaramonti [14] based on an externally fired gas turbine using solid biomass and topping combustion with natural gas to increase the efficiency. Pantaleo et al. [15] studied a techno-economic analysis of a similar system. A comprehensive review of externally fired gas turbines is presented Al-attab and Zainal [16].

Some studies considering the integration of biomass gasification gas with an externally fired gas turbine was summarized previously. As can be seen, externally fired gas turbines offer a potential option to use biomass gasification gas in a more simple way. In this work, the experimental data of a prototype plant from Compower $A B$ [17] is used in a simulation in order to evaluate the effect of different fuels based on biomass gasification gas and mixtures with methane on the performance of the externally fired micro gas turbine prototype. The effect of materials that can deposit in heat transfer surfaces as a result of using biomass gasification gas with less strict cleaning requirements is also analyzed.

\section{Methodology}

The study is divided in two parts. First, a short description of the plant layout is given. Then, the simulation of the system is explained.

\subsection{Description of the externally fired micro gas turbine unit}

The microturbine prototype was manufactured by Compower AB [17]. This system consists of a compressor, a turbine, a high temperature heat exchanger, a natural gas burner with the possibility to operate with biogas, and a water heat exchanger. The layout of the system is shown in Fig. 1. In this prototype, the air exiting the turbine is mixed with the flue gases from the combustor in order to limit the hot side inlet temperature to the heat exchanger to 
$650^{\circ} \mathrm{C}$ [18]. This is due to limitations of the material. The high temperature heat exchanger is a corrugated counter flow plate heat exchanger [19].

The fuel used to test the operation of this system was a mixture containing $35 \% \mathrm{CO}_{2}$ and $65 \% \mathrm{CH}_{4}$ volume/volume $(\mathrm{v} / \mathrm{v})$. This fuel mixture is named biogas hereafter. The measurements from the tests at steady state conditions are shown in Table 1. Compower $A B$ estimated an error for the measurements of around $\pm 5 \%$. The system was designed to produce $5 \mathrm{kWe}$ and $17 \mathrm{~kW}$ th energy. However, during the test the power did not exceed 2 kWe. This was due to an unsatisfactory design of the compressor and turbine to reach the power of $5 \mathrm{kWe}$.

In this work the integration of this prototype with a biomass gasifier is considered. The layout of the system studied is shown in Fig. 2. Removal of particles and dust is considered to some extent. For this reason, depending on the cyclone and filter to be used, the fuel inlet temperature is considered to be in a range of $150^{\circ} \mathrm{C}$ to $750^{\circ} \mathrm{C}$. It is important to note that for this study, the gasifier, cyclone and filter did not form part of the simulation. Instead, typical composition of biomass gasification gas was taken into account.

\subsection{Simulation of the system}

The simulation package Aspen Plus [20] was used to simulate the complete system and Matlab [21] was used to develop a detailed model of the heat exchanger. Information regarding the detailed model can be found in [22]. The following considerations have been assumed for the study:

- The system is operating at steady state conditions.

- Complete conversion of the fuel to carbon dioxide and water is assumed.

- Thermal losses were considered negligible.

- Tar components are represented by benzene at three different concentration rates.

\subsubsection{Description of the model}

The components modeled in Aspen Plus [20] were the combustor, the compressor, the turbine, and the water heat exchanger. The main heat exchanger was also simulated in Aspen plus using the results obtained from the detailed model in Matlab [21]. 
218 The combustor is designed for natural gas with the possibility to operate with biogas. The 219 power given to the system is about $30 \mathrm{~kW}$. According to the manufacturer an excess air of $20 \%$ was used in the tests. The fuel mass flow rate was then calculated by:

$$
\% \text { Excess air }=\frac{m_{\text {air combustor }}-m_{\text {air stoic hiometric }}}{m_{\text {air stoic hiometric }}}
$$

The stoichiometric air to fuel ratio is:

$$
A F_{\text {stoic hiometric }}=\left(\frac{m_{\text {air }}}{m_{\text {fuel }}}\right)_{\text {stoic hiometric }}
$$

For the validation of the system, biogas with a composition of $\mathrm{CH}_{4} 65 \%$ and $\mathrm{CO}_{2} 35 \%$ volume/volume (v/v) was used in the model. The stoichiometric air to fuel ratio for this mix is $A F_{\text {stoichiometric }}=6.21$.

In order to investigate the effect of biomass gasification gas and mixtures of biomass derived gas with methane on the performance of the cycle, simulations were carried out changing the composition of the fuel and the fuel inlet temperature to the combustor. The power provided by the combustor was kept constant at $30 \mathrm{~kW}$ for all the fuels.

In these studies, the gasifier itself was not included in the simulation. Instead, a typical composition of the product gas was used directly. This composition corresponds to wood as feedstock from a downdraft gasifier [23]. In order to represent tar, benzene was added to this composition at three different concentrations 1,10 , and $100 \mathrm{~g} / \mathrm{Nm}^{3}$ (hereafter named $\mathrm{m} 1, \mathrm{~m} 10$, and $\mathrm{m} 100$ respectively). Additionally, in order to study the effect of mixtures of biomass gasification gas with methane, two more fuel compositions were added to the analysis. These two fuel gas mixtures contained methane for 10 and $50 \%$ of the burner power. The compositions of the fuels used in the simulations are shown in Tables 2 and 3.

The fuel inlet temperature was varied for all the fuel mixtures presented in Tables 2 and 3 from 150 to $750^{\circ} \mathrm{C}$ [23]. In order to have comparable results, all fuels were simulated at the same temperature. 
The chemical reactions considered for the combustion process were:

$$
\begin{gathered}
2 \mathrm{CO}+\mathrm{O}_{2} \rightarrow 2 \mathrm{CO}_{2} \\
2 \mathrm{H}_{2}+\mathrm{O}_{2} \rightarrow 2 \mathrm{H}_{2} \mathrm{O} \\
\mathrm{CH}_{4}+2 \mathrm{O}_{2} \rightarrow \mathrm{CO}_{2}+2 \mathrm{H}_{2} \mathrm{O} \\
2 \mathrm{C}_{6} \mathrm{H}_{6}+15 \mathrm{O}_{2} \rightarrow 12 \mathrm{CO}_{2}+6 \mathrm{H}_{2} \mathrm{O}
\end{gathered}
$$

243

244

245

246

247

248

249

250

251

252

253

254

255

256

257

\subsubsection{Compressor and turbine}

For the compressor and turbine, the pressure ratios and isentropic efficiencies were calculated from the measured values (Table 1). Equations (7) and (8) were used to calculate the isentropic efficiencies for the compressor and turbine.

$$
\begin{gathered}
\eta_{s c}=\frac{T_{1}}{T_{2}-T_{1}} *\left[\left(\frac{P_{2}}{P_{1}}\right)^{\frac{\gamma-1}{\gamma}}-1\right] \\
\eta_{S T}=\frac{T_{3}-T_{4}}{T_{3} *\left[1-\frac{1}{\left.\left(\frac{P_{3}}{P_{4}}\right)^{\frac{\gamma-1}{\gamma}}\right]}\right.}
\end{gathered}
$$

\subsubsection{Heat exchanger}

A detailed model of the heat exchanger has been developed in Matlab [21]. The model is based on a correlation that was adjusted to the experimental results. Further details of the model can be found in [22]. The overall heat transfer coefficient calculated with Matlab [21] has been used in the Aspen Plus [20] simulations.

\subsubsection{Water heat exchanger}

For this component, a water inlet temperature of $20^{\circ} \mathrm{C}$ was considered. The heat transfer area corresponding to this device is about $0.83 \mathrm{~m}^{2}$. The water outlet temperature was $60^{\circ} \mathrm{C}$ or slightly above depending on the fuel type and hot side outlet temperature from the main heat exchanger. The water mass flow rate was assumed to be $0.097 \mathrm{~kg} / \mathrm{s}$.

\subsubsection{Electrical and thermal efficiencies}

The electrical power output was calculated from: 


$$
P_{e l}=\left(P_{T} * \eta_{\text {mec }}-P_{C}\right) * \eta_{\text {generator }}
$$

260 From the manufacturer data, the mechanical efficiency is assumed to be 0.99 while the

261 generator efficiency is 0.93 .

262 Equations (10) and (11) were used to calculate the compressor and turbine power $\left(\mathrm{P}_{\mathrm{C}}\right.$ and $\left.263 \mathrm{P}_{\mathrm{T}}\right)$.

$P_{C}=m_{\text {air to compressor }} * C p_{\text {air } 1-2} *\left(T_{2}-T_{1}\right)$

$P_{T}=m_{\text {air to compressor }} * C p_{\text {air } 3-4} *\left(T_{3}-T_{4}\right)$

264 Equation (12) was used to calculate the thermal power output $\left(P_{t h}\right)$.

$P_{t h}=m_{w a t e r} C p_{\text {water }}\left(T_{w, \text { in }}-T_{w, o u t}\right)$

265 The electrical and overall efficiencies were calculated using Equations (13) and (14).

$\eta_{e l}=\frac{P_{e l}}{m_{f u e l} L H V}$
$\eta_{C H P}=\frac{P_{e l}+P_{t h}}{m_{\text {fuel }} L H V}$

The electrical and overall efficiencies were calculated based on the fuel gas mass flow rate.

The calculation was not based on the fuel mass rate of the solid biomass entering the gasifier. Additionally, the lower heating value (LHV) of the gas was used.

\subsubsection{Parameter variations}

The parameters that have been varied in the analysis can be divided in three parts:

271 First, the effect of the fuel type and fuel inlet temperature to the combustor on the

272 performance of the cycle was analyzed. In this analysis, the composition of the fuels varied

273 together with their corresponding lower heating value and fuel inlet temperature to the combustor.

275 Second, the amount of air excess air for each type of fuel was varied between $20 \%$ and $43 \%$ in order to meet the operation temperature limit for the heat exchanger $\left(650^{\circ} \mathrm{C}\right)$. 
Additionally, the cycle performance was studied when considering an operation of the heat exchanger up to $850^{\circ} \mathrm{C}$. For this case, the burner power was the manipulated parameter.

Third, the effect on the cycle performance of deposit materials placed in the heat transfer surface was analyzed. In this analysis a range of thicknesses of deposit materials was considered as such. The growth of fouling over time was not considered in this study. The deposit materials from combustion of biomass gasification gas can have different composition depending on the contaminants present in the fuel gas. The conductivity of these deposit materials were varied in a range of values corresponding to soot with 0.07 $\mathrm{W} / \mathrm{m} * \mathrm{~K}[24$ ] to components such as alkali metals like $\mathrm{KCl}$ and $\mathrm{NaCl}$ with $2.08-3.78 \mathrm{~W} / \mathrm{m} * \mathrm{~K}$ [25].

\section{Results and discussion}

\subsection{Validation of the model}

In order to predict the behavior of the externally fired gas turbine unit with different fuels, the model was validated with experimental data provided by Compower $A B$ [17]. The measured parameters against the parameters calculated by the model are shown in Tables 4 and 5 . The measured parameters were obtained from average values extracted from the tests. All the parameters are measured at steady state conditions and at a generator speed of about 130,000 rpm. The measured temperatures are: outlet temperature from the compressor $\left(T_{2}\right)$, temperature from the hot side inlet to the heat exchanger $\left(T_{6}\right)$, turbine inlet temperature $\left(T_{3}\right)$, and the turbine outlet temperature $\left(T_{4}\right)$. The measured temperature from the hot side inlet to the heat exchanger $\left(T_{6}\right)$ was calculated from measured parameters such as the excess air, the air to combustion mass flow rate, the compressor air mass flow rate, and the turbine outlet temperature $\left(T_{4}\right)$. This was due to uncertainty in the measurement of $T_{6}$. In order to compare $T_{6}$ with the calculated value from the simulation, it will be included in the validation as one of the measured parameters since it is calculated from measured temperatures and mass flow rates. Table 5 presents the overall heat transfer coefficient $(U)$ and the power output $\left(\mathrm{P}_{\mathrm{el}}\right)$ calculated from the experimental data and the values calculated by the model. The deviations of the model range from $\pm 0.2 \%$ to $\pm 4.3 \%$. The smallest deviations are detected for the outlet temperatures from the compressor while the largest deviations correspond to the electrical power output and the overall heat transfer 
coefficient. These differences are due to the implications of the assumptions of isentropic efficiencies, complete combustion, and neglected heat losses in the simulation of the cycle.

\subsection{Effect of the fuel type on the performance of the cycle}

The fuel compositions considered for this section have been shown earlier in the text in Tables 2 and 3 with their corresponding lower heating value (LHV).

\subsubsection{Effect of fuel type and fuel inlet temperature to the combustor}

Fig. 3 shows the electrical power output $\left(P_{\mathrm{el}}\right)$ versus the fuel inlet temperature to the combustor for all the fuel types studied. Fig. 3a shows the fuels with no addition of methane while Fig.3c shows the fuels with natural gas addition for $50 \%$ of the burner power. The electrical power output for all the fuels studied is compared to that of methane and biogas. As can be seen in all cases, the electrical power output increases as the fuel inlet temperature to the combustor increases. The largest difference is seen for the fuels with no addition of methane where the electrical power output of $m 100, m 10$, and $m 1$ is higher than that of the same fuels at $150^{\circ} \mathrm{C}$ by $12 \%, 20 \%, 21 \%$ respectively (Fig. 3a). Methane and biogas show the lowest increase in electrical power output.

The electrical power output $\left(P_{\mathrm{el}}\right)$ for the fuel mixtures $\mathrm{m} 100, \mathrm{~m} 100-10, \mathrm{~m} 100-50, \mathrm{~m} 10-50$, and m1-50 exceed that of methane and biogas at a certain fuel inlet temperature to the combustor. As marked in Fig. 3, for the fuel mixture m100 (with no addition of methane) such a point is given at a fuel inlet temperature of about $660^{\circ} \mathrm{C}$ and $220^{\circ} \mathrm{C}$ for methane and biogas respectively. For the fuel mixture $\mathrm{m} 100-10$, this point is given at around $650^{\circ} \mathrm{C}$ and $150^{\circ} \mathrm{C}$ with respect to methane and biogas. Finally, for the fuels with the largest addition of methane, this change occurs at $580^{\circ} \mathrm{C}$ for $\mathrm{m} 100-50$ with respect of methane and at $480^{\circ} \mathrm{C}$ for m10-50 and m1-50 with respect of biogas. These points are marked in Fig. 3. The fuel mixtures $m 1, m 10, m 1-10$, and $m 10-10$ reach about the same power output of biogas at high fuel inlet temperatures to the combustor. As the addition of methane increases in the fuel mixture, the fuels based on biomass gasification gas resemble more the behavior of methane.

The observations previously described are due to the flue gas temperatures as indicated in Fig. 4. The flue gas temperatures for all the fuels entering the combustor at temperatures of 
$150^{\circ} \mathrm{C}$ and $750^{\circ} \mathrm{C}$ are shown in Fig. 4 for $20 \%$ excess air. As can be seen there is an increase of the flue gas temperature for all the fuels at $750^{\circ} \mathrm{C}$ compared to that at $150^{\circ} \mathrm{C}$. The lowest increase corresponds to methane with $3 \%$ and the highest increase corresponds to the fuel mixture $\mathrm{m} 1$ with $13 \%$.

In Fig. 4 it can also be seen that while there is a larger discrepancy of the flue gas temperatures of the fuels entering the combustor at low temperatures, this discrepancy reduces at high fuel inlet temperatures. For instance, the flue gas temperature of $m 1$ is lower than that of methane by $12 \%$ at $150^{\circ} \mathrm{C}$. However, at $750^{\circ} \mathrm{C}$ the flue gas temperature of $\mathrm{m} 1$ is lower than that of methane by $4 \%$.

The differences mentioned previously in the flue gas temperatures are due to the different composition of the fuels and larger volume of biomass derived fuels compared to that of methane. The fuels with larger volume store more sensible heat that is later released during combustion.

Fig. 5 shows the electrical power output $\left(P_{e l}\right)$ against the fuel type and the flue gas temperature. As can be seen at $150^{\circ} \mathrm{C}$ (Fig.5a) the highest electrical output power corresponds to the fuels with higher flue gas temperatures. For instance, the power output of methane is higher than that of the fuel mixture with the lowest flue gas temperature $(\mathrm{m} 1)$ by $18 \%$. The flue gas temperature is correspondingly higher by $12 \%$. Additionally, it can also be seen that the electrical power output of m100-50 slightly exceeds that of biogas by $3 \%$. However, the lower heating value of biogas (LHV) is higher than that of $\mathrm{m} 100-50$ by $37 \%$. For a fuel inlet temperature to the combustor of $400^{\circ} \mathrm{C}$, the electrical power output of the fuel mixtures with higher concentration of benzene and higher addition of methane show about the same electrical power output of biogas. For fuels entering the combustor at $750^{\circ} \mathrm{C}$, the electrical power output and flue gas temperature of methane are still higher than those of $\mathrm{m} 1$ by $4 \%$. However, the difference is smaller than at $150^{\circ} \mathrm{C}$. The electrical power output of m100, m100-10 and m100-50 is about the same of methane. However, the LHV of methane is six and four times larger than that of the same fuels. The electrical power output of the fuels without addition of methane is about the same of the fuels with an addition of methane for $10 \%$ and $50 \%$ of the burner power. For fuels entering the combustor at high fuel inlet temperatures, the addition of methane does not have a significant effect. 
Fig. 6 shows the electrical power output against the fuel type and the turbine inlet temperature (TIT). As can be seen the highest turbine inlet temperature corresponds to the fuels with highest electrical output power for all the fuels. Comparing Figs. 5 and 6, it can also be seen that the turbine inlet temperature conducts in a similar manner as the flue gas temperatures.

For a specific heat exchanger, the temperature and mass flow rates for the cold and hot side affect the turbine inlet temperature of the externally fired gas turbine. While the parameters for the cold side are kept constant for all the fuels, the hot side temperature depends on the flue gas temperature and exhaust temperature from the turbine.

The exhaust temperature from the turbine and hot side inlet temperature to the heat exchanger are shown in Fig. 7. The exhaust temperature from the turbine and the hot side inlet temperature behave in a similar manner as the turbine inlet temperature. This relation is expected since the higher the hot side inlet temperature the higher the turbine inlet temperature will be and as a result the higher the exhaust temperature.

It would be expected that fuels with higher LHV (lower heating value) show higher temperatures and produce higher electrical output power. This is true to some extent for some fuels however the composition of the fuels, the fuel inlet temperature to the combustor, the flue gas temperature and the turbine inlet temperature also affect the system studied. It is important to note that in this work, the lower heating value (LHV) between gases is compared. For solid biomass the effect can be different as studied by Cordiner and Mulone [13].

The electrical and overall efficiencies for this system and all the fuel types are shown in Fig. 8. Both are higher for the fuels with higher concentration of benzene and higher fuel inlet temperature. The electrical efficiency varies from 5 to $7 \%$ while the overall efficiency is about $61 \%$ for all the fuels.

\subsubsection{Performance of the cycle for a temperature limit in the heat exchanger}

The operation temperature for the heat exchanger in this system is limited to $923 \mathrm{~K}\left(650^{\circ} \mathrm{C}\right)$. For this system to run with the fuel compositions and inlet temperatures to the combustor previously indicated, the excess air would require to increase. This is to lower the hot side 
inlet temperature to the heat exchanger to the limit for its operation. Fig. 7 shows the hot side inlet temperature of the heat exchanger for an excess air of $20 \%$. As can be seen, most of the fuels show temperatures above 923K. Fig. 9 shows the hot side inlet temperature to the heat exchanger and electrical power output for fuel inlet temperatures to the combustor of $150^{\circ} \mathrm{C}$ and $400^{\circ} \mathrm{C}$ with $43 \%$ excess air. As can be seen, for the temperature limit of the heat exchanger, the electrical power output is about the same regardless of the fuel composition. However, the fuel inlet temperature to the combustor is lower for the fuels with higher content of benzene and higher addition of methane. For instance, the fuel mixtures m10 and m1-10 show a hot side inlet temperature of about $923 \mathrm{~K}$ and an electrical power output of about $1.6 \mathrm{~kW}$ for a fuel inlet temperature to the combustor of $400^{\circ} \mathrm{C}$. The fuel mixture m100 shows about the same hot side inlet temperature and electrical power output but for a fuel entering the combustor at $150^{\circ} \mathrm{C}$. It can be said that for a temperature limit in the heat exchanger, the composition of the fuels does not have a significant effect on the electrical power output. The electrical and overall efficiencies of the system with an excess air of $43 \%$ are shown in Fig. 10. The electrical efficiency varies in the range of 4.8 to $6 \%$ while the overall efficiency is about 60.5 to $61 \%$. The electrical efficiency is low due to the low operation temperature of the heat exchanger.

For a heat exchanger material able to work at temperatures of about $850^{\circ} \mathrm{C}$, a higher burner power would be required in this system. Fig. 11a shows the hot side inlet temperature to the heat exchanger against the burner power for the fuel mixtures $\mathrm{m} 100, \mathrm{~m} 10$ and $\mathrm{m} 1$ at different fuel inlet temperatures to the combustor. As can be seen, for a hot side inlet temperature to the heat exchanger of $1123 \mathrm{~K}\left(850^{\circ} \mathrm{C}\right)$ a burner power of about $40 \mathrm{~kW}$ is required for the fuel mixture $\mathrm{m} 100$ at $750^{\circ} \mathrm{C}$ of fuel inlet temperature to the combustor. For the fuel mixtures $\mathrm{m} 10$ and $\mathrm{m} 1$ the burner power required is larger. This is due to the increase in energy content as $\mathrm{m} 100$ contains higher concentration of benzene. The electrical power output for all the fuels against the burner power is shown in Fig. 11b. As can be seen, the electrical power output is not greatly affected by the composition of the fuels for a burner power output corresponding to a fixed hot side inlet temperature in the heat exchanger. The operation temperature of the heat exchanger and the turbine inlet temperature have a greater effect than the composition of the fuels. The small difference in the electrical power output between fuels $\mathrm{m} 100$ and $\mathrm{m} 1$ is due to larger mass flow rates 
involved for the fuel mixture $\mathrm{m} 1$ than for the fuel mixture $\mathrm{m} 100$. The electrical and overall efficiencies for this case are shown in Fig. 12. The electrical efficiency varies from $10 \%$ to $11 \%$ while the overall efficiency varies from 68 to $70 \%$. The lowest electrical efficiency corresponds to the fuel mixture $\mathrm{m} 1$ at a fuel inlet temperature to the combustor of $150^{\circ} \mathrm{C}$ while the highest electrical efficiency corresponds to m100 at a fuel inlet temperature of $750^{\circ} \mathrm{C}$. The corresponding overall efficiency for $\mathrm{m} 1$ is slightly larger than that of $\mathrm{m} 100$. This is again due to the slightly larger mass flow rate of the fuel mixture $\mathrm{m} 1$. It can also be seen that high fuel inlet temperatures to the combustor can result in slightly higher electrical efficiencies.

For a fixed hot side inlet temperature, the electrical power output is not greatly affected by the composition of the fuels. The hot side inlet temperature to the heat exchanger is an important parameter since it influences the turbine inlet temperature. Increasing the excess air reduces the efficiencies in the system.

\subsection{Effect of deposit materials in the heat exchanger}

If the use of biomass gasification gas with less cleaning requirements is considered for externally fired gas turbines, it is important to study the effect on the electrical power output of increase thicknesses of deposit materials in the heat transfer surfaces. In the system studied, the exhaust air from the turbine is mixed with the flue gases and represents the hot side mass flow rate of the heat exchanger as can be seen in Figure 1. As a result, the pressure drop in the hot side of the heat exchanger can affect the performance of the turbine. The pressure ratio and the turbine inlet temperature are the most important parameters that affect the performance of a gas turbine.

In a previous work [22] it was observed that the effectiveness of the heat exchanger depends on the characteristics of the deposit material when fouling is considered. The increase of thickness of deposit materials in this work is considered as such and it is not representing an increase over time. The buildup of fouling over time is dependent of several parameters such as the velocity of the fluids, the geometry of the heat exchangers, the fluids themselves and temperatures. In this work, a simple approach to consider the effect deposit materials was used. This approach is explained in more detail in a previous work [22]. The thermal conductivities of the deposit materials and their thickness over the heat transfer 
surface are considered. Fig. 13 shows the effect on the electrical power output of different thicknesses of deposit materials and the corresponding pressure drop $(\Delta \mathrm{P})$ in the hot side of the heat exchanger for a range of thermal conductivities varying from 0.07 to $3.78 \mathrm{~W} / \mathrm{m} * \mathrm{~K}$. As can be seen, the electrical power output reduces for high thicknesses of deposit materials and pressure drop for low thermal conductivities. This is due to increased resistance due to fouling resulting in a decrease of effectiveness of the heat exchanger and thus a decrease in the electrical power output. For deposit materials with high thermal conductivities, the electrical power output shows an increase with the increment in the thickness of deposit materials and pressure drop. This effect is due to reduced hydraulic diameters when the thickness of deposit materials increases increasing the velocity of the fluids and hence increasing the heat transfer coefficient [22]. The reduced hydraulic diameters also increase the pressure drop and this reduces the turbine pressure ratio.

For high thermal conductivities, the effect of reduced turbine pressure ratios is not clear although the pressure drop increases. This occurs until a point in which the power output starts decreasing. This is not shown as clearly for the case of low thermal conductivity since the effect of lower working temperatures covers the effect of the pressure drop. At a thickness of deposit material of about $0.15 \mathrm{~mm}$ (marked with a vertical line in Fig.13) corresponding to a pressure drop of almost $3000 \mathrm{~Pa}(11 \%$ higher than the pressure drop of the heat exchanger under clean conditions) there is a variation of around $\pm 10 \%$ of the electrical power output when no fouling is considered depending on the thermal conductivity of the deposit material.

\section{Conclusions}

Simulations of an externally fired gas turbine prototype were carried out with different fuels. The fuels considered were methane, biogas, biomass gasification gas varying the concentrations of benzene representing tar as 100,10 , and $1 \mathrm{~g} / \mathrm{Nm}^{3}$ and the same fuel mixtures of biomass gasification gas varying the concentration of methane at levels of 10 and $50 \%$ of the burner power. Methane was used as base line to compare the fuel types. Additionally, the effect of varying the fuel inlet temperature to the combustor from $150^{\circ} \mathrm{C}$ to $750^{\circ} \mathrm{C}$ was analyzed. The base line for this analysis was the operating conditions of the fuels at $150^{\circ} \mathrm{C}$. Moreover, the effect on the electrical power output of different thicknesses of 
deposit materials and pressure drop in the heat exchanger was analyzed. The main conclusions are as follows:

- In general, the electrical power output increases as the fuel inlet temperature to the combustor increases. However, this increase is different depending on the fuel composition. This affects the flue gas temperatures and thus the turbine inlet temperature.

- The electrical power output $\left(P_{G T e l}\right)$ for all the fuel mixtures with higher benzene content exceeds that of methane and biogas at a certain fuel inlet temperature.

- The addition of methane to the fuel mixtures does not have a significant effect on the electrical power output.

- It would be expected that fuels with higher LHV show higher temperatures and higher electrical output power. However, the composition of the fuels affects the flue gas temperature and thus the turbine inlet temperature. Both play an important role if the hot side inlet temperature in the heat exchanger is not restricted.

- For a fixed working temperature of the heat exchanger the effect of the composition of the fuels is not significant on the electrical power output. This is because the operation temperature of the material limits the turbine inlet temperature for a specific heat exchanger. The electrical efficiency can be slightly higher for fuels entering the combustor at high temperatures.

- High pressure drops due to increased thickness of deposit materials can affect the electrical power output of the system. However, this effect is much smaller than the effect of the reduced working temperatures as the thickness of deposit materials increase.

Although the composition of the fuels does not have a large effect on the electrical power output for a specific heat exchanger, it is important to consider the fuel contents with regards fouling particles for the heat exchanger operation. High temperature operation of the heat exchanger in this system allows a better use of the sensible heat in biomass gasification gas. There is potential in this system when operating at high temperatures. The results presented in this work are important when deciding the conditions of the fuel to be used in externally fired gas turbines. These results also contribute towards further development of externally fired gas turbines using biomass derived gas as fuel. 


\section{Acknowledgements}

518 The financial support of the Swedish International Development Cooperation Agency (SIDA),

519 the division of Heat and Power Technology, Department of Energy Technology at Royal

520 Institute of Technology (KTH) in Sweden, and Universidad Mayor de San Simon (UMSS) in

521 Bolivia are acknowledged for this work. InnoEnergy "STandUP for Energy" and Compower AB

522 are acknowledged for providing data of the externally fired gas turbine unit.

References

524 [1] J. A. Ruiz, M. C. Juárez, M. P. Morales, P. Muñoz, and M. A. Mendívil, "Biomass 525 gasification for electricity generation: Review of current technology barriers," Renew. Sustain. Energy Rev., vol. 18, pp. 174-183, 2013.

527

[2] M. Asadullah, "Barriers of commercial power generation using biomass gasification gas: A review," Renew. Sustain. Energy Rev., vol. 29, pp. 201-215, Jan. 2014.

529

[3] J. Held, "Gasification - Status and technology," Malmö, Sweden, 2012.

530

[4] A. V Bridgwater, "The technical and economic feasibility of biomass gasification for power generation," Fuel, vol. 74, no. 5, pp. 631-653, 1995.

[5] M. Kautz and U. Hansen, "The externally-fired gas-turbine (EFGT-Cycle) for decentralized use of biomass," Appl. Energy, vol. 84, no. 7-8, pp. 795-805, Jul. 2007.

[6] L. Dong, H. Liu, and S. Riffat, "Development of small-scale and micro-scale biomassfuelled CHP systems - A literature review," Appl. Therm. Eng., vol. 29, no. 11-12, pp.

[7] U. Arena, F. Di Gregorio, and M. Santonastasi, “A techno-economic comparison between two design configurations for a small scale, biomass-to-energy gasification based system," Chem. Eng. J., vol. 162, no. 2, pp. 580-890, 2010.

[8] J. Schulte-Fischedick, V. Dreißigacker, and R. Tamme, "An innovative ceramic high temperature plate-fin heat exchanger for EFCC processes," Appl. Therm. Eng., vol. 27, no. 8-9, pp. 1285-1294, Jun. 2007. 
[9] K. A. Al-attab and Z. A. Zainal, "Turbine startup methods for externally fired micro gas turbine (EFMGT) system using biomass fuels," Appl. Energy, vol. 87, no. 4, pp. 13361341, 2010.

[10] D. Vera, F. Jurado, and J. Carpio, "Study of a downdraft gasifier and externally fired gas turbine for olive industry wastes," Fuel Process. Technol., vol. 92, no. 10, pp. 1970-1979, Oct. 2011.

[11] A. Datta, R. Ganguly, and L. Sarkar, "Energy and exergy analyses of an externally fired gas turbine (EFGT) cycle integrated with biomass gasifier for distributed power generation," Energy, vol. 35, no. 1, pp. 341-350, Jan. 2010.

[12] S. Soltani, M. Yari, S. M. S. Mahmoudi, T. Morosuk, and M. A. Rosen, "Advance exergy analysis applied to an externally-fired combined-cycle power plant integrated with a biomass gasification unit," Energy, vol. 59, pp. 775-780, 2013.

[13] S. Cordiner and V. Mulone, "Experimental-numerical analysis of a biomass fueled microgeneration power-plant based on microturbine," Appl. Therm. Eng., 2014.

[14] G. Riccio and D. Chiaramonti, "Design and simulation of a small polygeneration plant using biomass and natural gas in a dual combustion micro gas turbine (BIO_MGT)," Biomass and Bioenergy, vol. 33, no. 11, pp. 1520-1531, 2009.

[15] A. Pantaleo, S. Camporeale, and N. Shah, "Natural gas-biomass dual fuelled microturbines: Comparison of operating strategies in the Italian residential sector," Appl. Therm. Eng., vol. 71, no. 2, pp. 686-696, 2014.

[16] K. A. Al-attab and Z. A. Zainal, "Externally fired gas turbine technology: A review," Appl. Energy, vol. 138, pp. 474-487, 2015.

[17] Compower AB, "Compower - Heat and power generated at home," Compower, 2014. [Online]. Available: www.compower.se/. [Accessed: 02-Feb-2014].

[18] CompowerAB, "Operating instruction manual - Micro gas turbine ET10," Stockholm, Sweden, 2010. 
569

570

571

572

573

574

575

576

577

578

579

580

581

582

[19] A. Malmquist, "Analysis of a gas turbine driven hybrid drive system for heavy vehicles," Royal Institute of Technology, Stockholm, Sweden, 1999.

[20] Aspen Plus v 8.0, “Aspen Plus ${ }^{\circledR}$." Aspen Technolog, Inc, USA, 2012.

[21] Matlab R2013b, "Matlab." The MathWorks, Inc, Natick, Massachusetts, 2013.

[22] F. Baina, A. Malmquist, L. Alejo, B. Palm, and T. Fransson, "Analysis of a hightemperature heat exchanger for an externally-fired micro gas turbine," Appl. Therm. Eng., vol. 75, pp. 410-420, 2014.

[23] C. Erlich and T. H. Fransson, "Downdraft gasification of pellets made of wood, palm-oil residues respective bagasse: Experimental study," Appl. Energy, vol. 88, no. 3, pp. 899-908, 2011.

[24] J. E. Hesselgreaves, "An approach to fouling allowances in the design of compact heat exchangers," Appl. Therm. Eng., vol. 22, no. 7, pp. 755-762, May 2002.

[25] Designed Institute for Physical Properties and AIChe, Knovel DIPPR Project 801 - Full Version. Design Institute for Physical Property Research/AIChE, 2012. 
Table 1 Measured parameters of the prototype. Data was provided by Compower AB.

\begin{tabular}{|c|c|c|c|c|}
\hline Parameters & Unit & Data 1 & Data 2 & Data 3 \\
\hline Generator speed & rpm & 130,821 & 131,148 & 131,257 \\
\hline Ambient temperature & $\mathrm{K}$ & 290.8 & 291.2 & 291.4 \\
\hline Ambient pressure & $\mathrm{kPa}$ & 102.9 & 102.9 & 102.9 \\
\hline \multicolumn{5}{|l|}{ Combustor } \\
\hline$\Delta \mathrm{P}$ combustor & $\mathrm{Pa}$ & 998.8 & 985.5 & 995.4 \\
\hline $\mathrm{m}_{\text {air combustor }}$ & $\mathrm{kg} / \mathrm{s}$ & 0.0117 & 0.0119 & 0.0120 \\
\hline$m *$ fuel & $\mathrm{kg} / \mathrm{s}$ & 0.0014 & 0.0014 & 0.0014 \\
\hline \multicolumn{5}{|l|}{ Compressor } \\
\hline Isentropic efficiency & - & 0.70 & 0.70 & 0.70 \\
\hline Pressure ratio compressor & - & 2.39 & 2.40 & 2.40 \\
\hline $\mathrm{P}$ out compressor & $\mathrm{kPa}$ & 246.3 & 246.9 & 247.1 \\
\hline $\mathrm{T}_{\text {out compressor }}\left(\mathrm{T}_{\text {in air side to } \mathrm{HX}}\right)$ & $\mathrm{K}$ & 409.1 & 409.6 & 409.9 \\
\hline $\mathrm{m}_{\text {air to the compressor }}$ & $\mathrm{kg} / \mathrm{s}$ & 0,0902 & 0.0916 & 0.0908 \\
\hline \multicolumn{5}{|l|}{ Turbine } \\
\hline Isentropic efficiency & - & 0.77 & 0.76 & 0.76 \\
\hline Pressure ratio turbine & - & 2.26 & 2.27 & 2.27 \\
\hline$P_{\text {in turbine }}$ & $\mathrm{kPa}$ & 241.6 & 242.3 & 242.5 \\
\hline$P_{\text {out turbine }}$ & $\mathrm{kPa}$ & 106.7 & 106.8 & 106.8 \\
\hline$T_{\text {in turbine }}(T I T)$ ( $T$ out air side to $\left.H X\right)$ & $\mathrm{K}$ & 857.7 & 862.3 & 864.5 \\
\hline$T_{\text {out turbine }}$ & K & 730.5 & 735.0 & 737.0 \\
\hline \multicolumn{5}{|c|}{ High temperature heat exchanger (HX) } \\
\hline $\mathrm{T}^{*}$ in gas side & $\mathrm{K}$ & 918.6 & 927.3 & 930.9 \\
\hline $\mathrm{T}^{*}$ out gas side & $\mathrm{K}$ & 535.2 & 538.9 & 536.1 \\
\hline$\Delta \mathrm{P}_{\text {gas side }}$ & $\mathrm{Pa}$ & 2,644 & 2,679 & 2,694 \\
\hline$\Delta \mathrm{P}_{\text {air side }}$ & $\mathrm{Pa}$ & 4,690 & 4,632 & 4,599 \\
\hline
\end{tabular}

*Data is based on calculations using mass and energy balances 
Table 2 Fuel compositions and their corresponding lower heating value

\begin{tabular}{llllllllll}
\hline \multirow{2}{*}{ Fuel type } & & \multicolumn{9}{c}{ Biomass gasification gas composition (\%volume) } & LHV \\
\cline { 2 - 10 } & & $\mathrm{CO}$ & $\mathrm{H}_{2}$ & $\mathrm{CH}_{4}$ & $\mathrm{CO}_{2}$ & $\mathrm{~N}_{2}$ & $\mathrm{H}_{2} \mathrm{O}$ & $\mathrm{C}_{6} \mathrm{H}_{6}$ & $\mathrm{MJ} / \mathrm{kg}$ \\
\hline Fuel $\left[1 \mathrm{~g} / \mathrm{Nm}^{3}\right]$ & $\mathrm{m}^{*}$ & 23.98 & 11.64 & 2.38 & 9.50 & 47.49 & 5.00 & 0.03 & 4.66 \\
Fuel $\left[10 \mathrm{~g} / \mathrm{Nm}^{3}\right]$ & $\mathrm{m} 10^{*}$ & 23.92 & 11.61 & 2.37 & 9.47 & 47.37 & 4.99 & 0.27 & 4.92 \\
Fuel $\left[100 \mathrm{~g} / \mathrm{Nm}^{3}\right]$ & $\mathrm{m} 100 *$ & 23.35 & 11.33 & 2.31 & 9.25 & 46.24 & 4.87 & 2.65 & 7.39 \\
\hline
\end{tabular}

* Reference name 
Table 3 Fuel compositions with methane addition

\begin{tabular}{|c|c|c|c|c|c|c|c|c|c|}
\hline \multicolumn{2}{|c|}{ Fuels mixed with natural gas } & \multicolumn{7}{|c|}{ Biomass gasification gas composition (\%volume) } & \multirow{2}{*}{$\begin{array}{c}\mathrm{LHV} \\
\mathrm{MJ} / \mathrm{kg}\end{array}$} \\
\hline & & $\mathrm{CO}$ & $\mathrm{H}_{2}$ & $\mathrm{CH}_{4}$ & $\mathrm{CO}_{2}$ & $\mathrm{~N}_{2}$ & $\mathrm{H}_{2} \mathrm{O}$ & $\mathrm{C}_{6} \mathrm{H}_{6}$ & \\
\hline Fuel ${ }^{* *}\left[1 \mathrm{~g} / \mathrm{Nm}^{3}\right]-10 \%$ & m1-10* & 23.60 & 11.45 & 3.94 & 9.35 & 46.73 & 4.92 & 0.03 & 5.11 \\
\hline Fuel ${ }^{* *}\left[1 \mathrm{~g} / \mathrm{Nm}^{3}\right]-50 \%$ & m1-50* & 20.92 & 10.15 & 14.83 & 8.29 & 41.43 & 4.36 & 0.02 & 8.47 \\
\hline Fuel ${ }^{* *}\left[10 \mathrm{~g} / \mathrm{Nm}^{3}\right]-10 \%$ & $\mathrm{~m} 10-10^{*}$ & 23.52 & 11.41 & 4.03 & 9.31 & 46.57 & 4.90 & 0.27 & 5.40 \\
\hline Fuel ${ }^{* *}\left[10 \mathrm{~g} / \mathrm{Nm}^{3}\right]-50 \%$ & $\mathrm{~m} 10-50^{*}$ & 20.70 & 10.04 & 15.51 & 8.20 & 41.00 & 4.32 & 0.24 & 8.92 \\
\hline Fuel ${ }^{*}\left[100 \mathrm{~g} / \mathrm{Nm}^{3}\right]-10 \%$ & m100-10* & 22.73 & 11.03 & 4.91 & 9.00 & 45.01 & 4.91 & 2.58 & 8.07 \\
\hline Fuel ${ }^{* *}\left[100 \mathrm{~g} / \mathrm{Nm}^{3}\right]-50 \%$ & m100-50* & 18.74 & 9.09 & 21.61 & 7.42 & 37.10 & 3.91 & 2.13 & 12.85 \\
\hline
\end{tabular}

* Reference name

** 10 and $50 \%$ is a share based on the thermal power output of the combustor 
Table 4 Measured temperatures against temperatures calculated by the model

\begin{tabular}{llll}
\hline Parameters & Data 1 & Data 2 & Data 3 \\
\hline $\mathrm{T}_{2 \text { measured, }} \mathrm{K}$ & 409.1 & 409.6 & 409.9 \\
$\mathrm{~T}_{2 \text { simulated, }} \mathrm{K}$ & 408.3 & 408.8 & 409.1 \\
Relative error, \% & 0.2 & 0.2 & 0.2 \\
$\mathrm{~T}_{3 \text { measured, }} \mathrm{K}$ & 857.7 & 862.3 & 864.5 \\
$\mathrm{~T}_{3 \text { simulated, }} \mathrm{K}$ & 870.7 & 872.9 & 880.2 \\
Relative error, \% & 1.5 & 1.2 & 1.8 \\
$\mathrm{~T}_{4 \text { measured, }} \mathrm{K}$ & 730.5 & 735.0 & 737.0 \\
$\mathrm{~T}_{4 \text { simulated, }} \mathrm{K}$ & 742.4 & 744.8 & 751.4 \\
Relative error, \% & 1.6 & 1.3 & 2.0 \\
$\mathrm{~T}_{6 \text { measured, }} \mathrm{K}$ & 918.6 & 923.3 & 926.8 \\
$\mathrm{~T}_{6 \text { simulated, }} \mathrm{K}$ & 928.5 & 931.2 & 938.7 \\
Relative error, \% & 1.1 & 0.9 & 1.3 \\
$\mathrm{~T}_{7 \text { measured, }} \mathrm{K}$ & 535.2 & 536.7 & 539.0 \\
$\mathrm{~T}_{7 \text { simulated, }} \mathrm{K}$ & 537.7 & 539.2 & 541.6 \\
Relative error, \% & 0.5 & 0.5 & 0.5 \\
\hline
\end{tabular}


Table 5 Measured and calculated overall heat transfer coefficient $(U)$ and electrical power output $\left(P_{e l}\right)$.

\begin{tabular}{llll}
\hline Parameters & Data 1 & Data 2 & Data 3 \\
\hline $\mathrm{U}_{\text {measured, }} \mathrm{W} / \mathrm{m}^{2} \mathrm{~K}$ & 47.7 & 48.5 & 47.0 \\
$\mathrm{U}$ calculated, $\mathrm{W} / \mathrm{m}^{2} \mathrm{~K}$ & 48.6 & 49.2 & 49.0 \\
Relative Error, \% & 1.9 & 1.4 & 4.3 \\
$\mathrm{P}_{\mathrm{el}}$ measured, $\mathrm{W}$ & 1724.0 & 1778.1 & 1763.0 \\
$\mathrm{P}_{\text {el calculated, }} \mathrm{W}$ & 1699.3 & 1707.6 & 1757.8 \\
Relative Error, \% & 1.4 & 4.0 & 0.3 \\
\hline
\end{tabular}




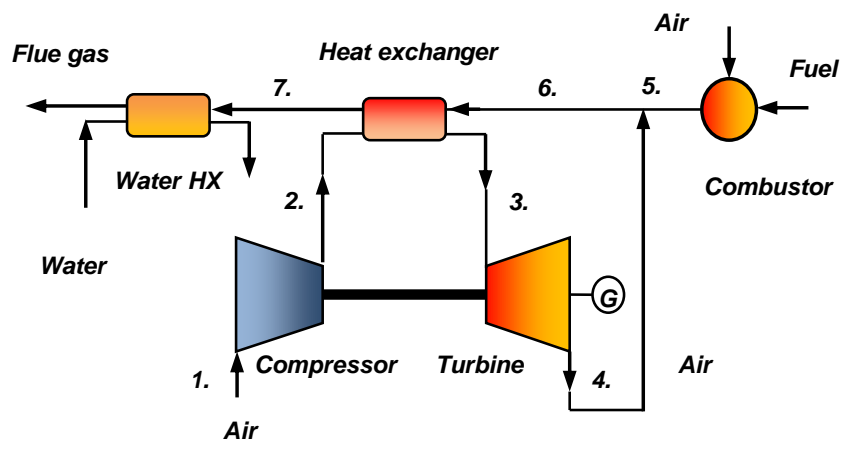

Fig. 1 Layout of the Compower externally fired micro turbine prototype 


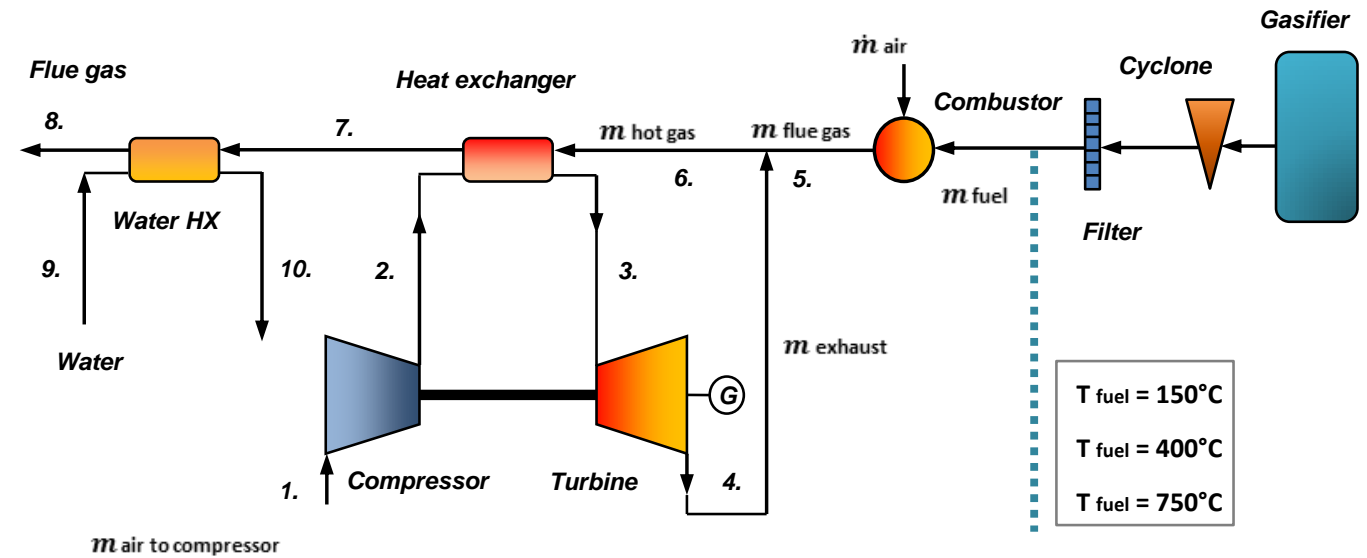

Fig. 2 Layout of the system 


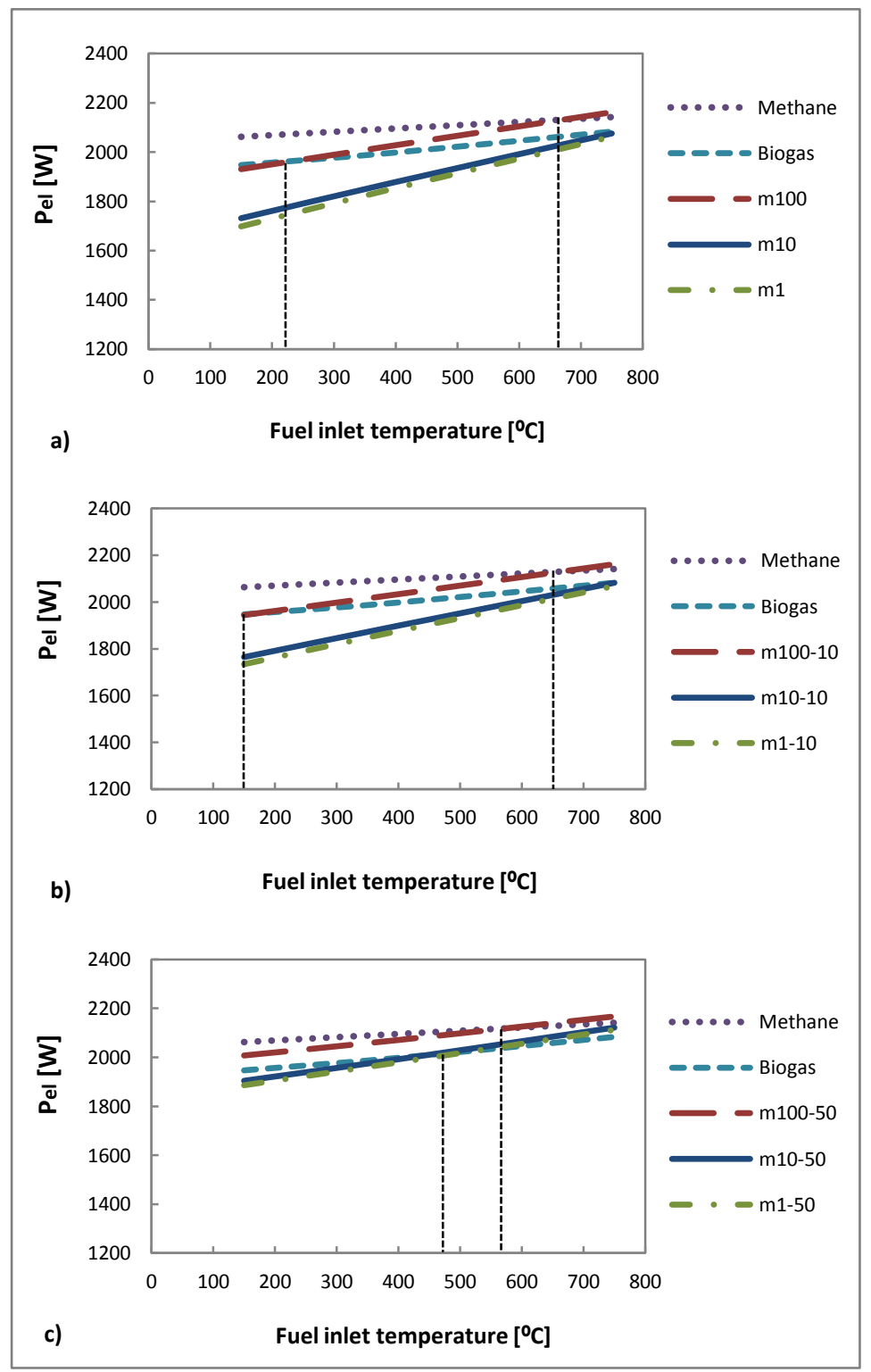

Fig. 3 Electrical power output (Pel) versus fuel inlet temperature. a) Fuels without methane b) Fuels with methane addition for $10 \%$ of the burner power c) Fuels with methane addition for $50 \%$ of the burner power 


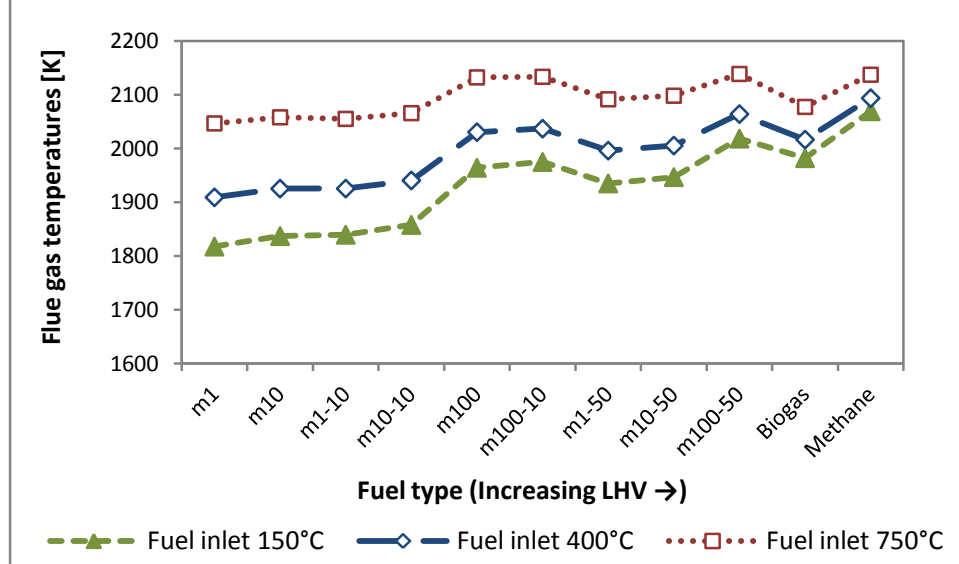

Fig. 4 Flue gas temperatures of the fuels at $20 \%$ excess air 


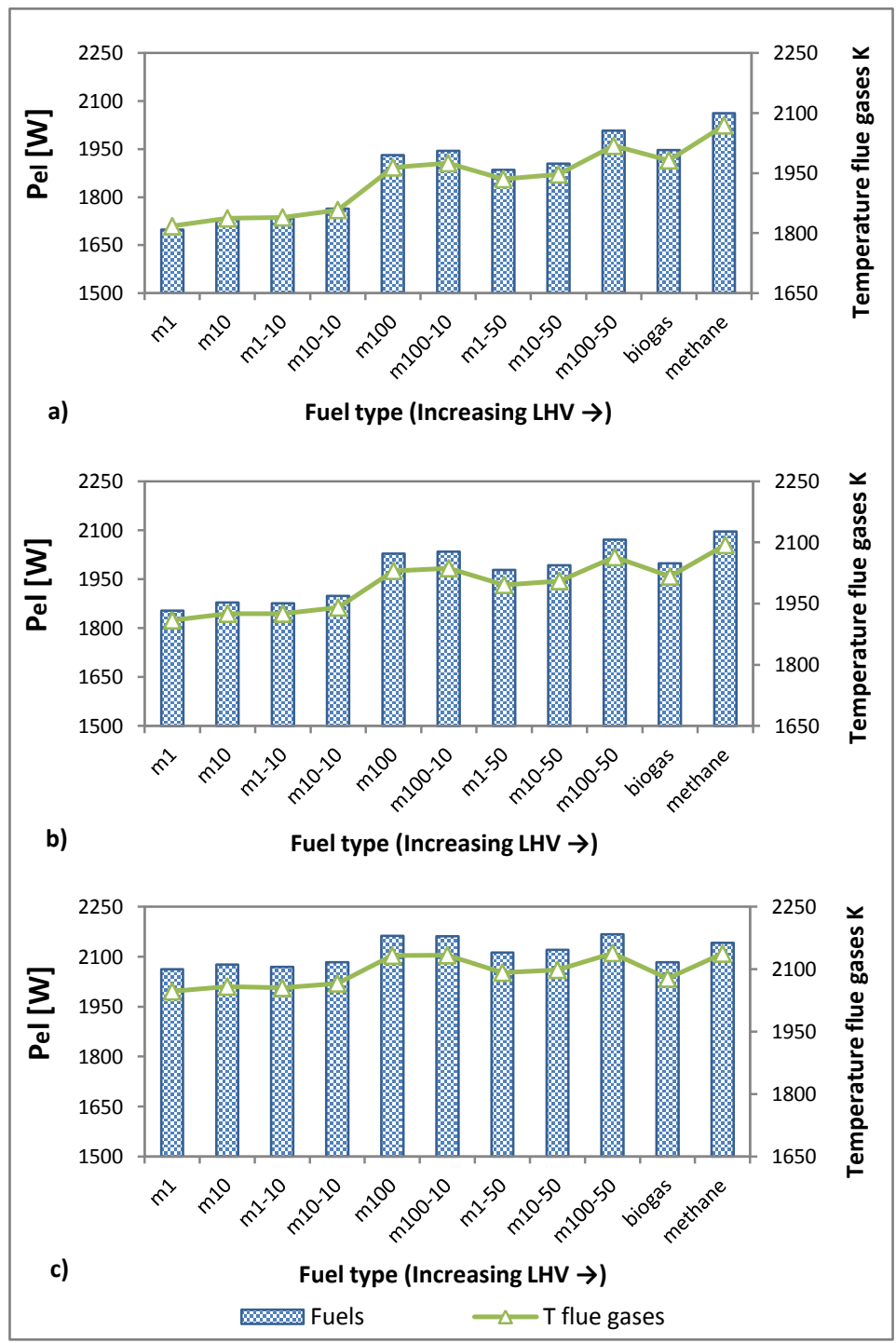

Fig. 5 Electrical power output (Pel) against the fuel type and flue gas temperature. a) Fuels inlet temperature $150^{\circ} \mathrm{C}$. b) Fuels inlet temperature $400^{\circ} \mathrm{C}$. c) Fuels inlet temperature $750^{\circ} \mathrm{C}$ 

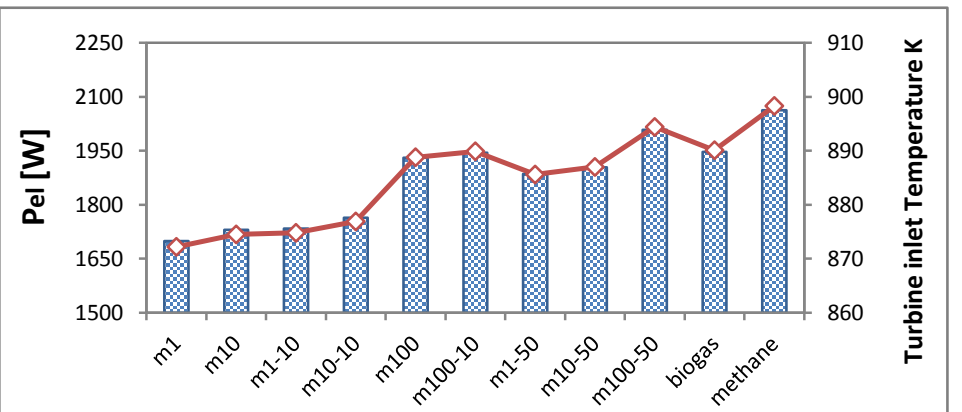

a)

Fuel type (Increasing LHV $\rightarrow$ )

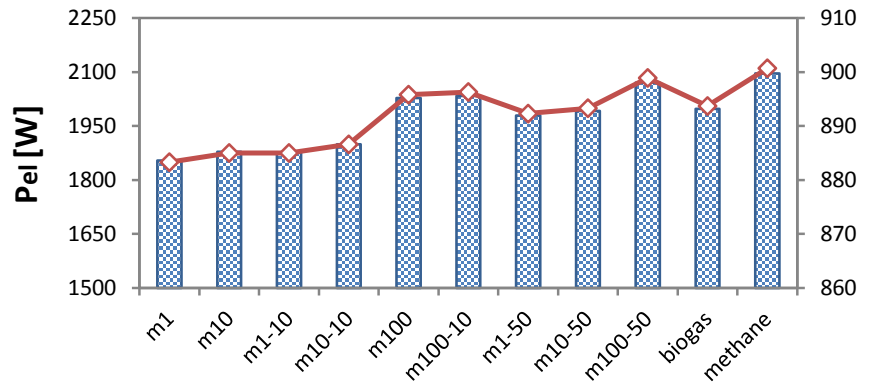

b)

Fuel type (Increasing LHV $\rightarrow$ )

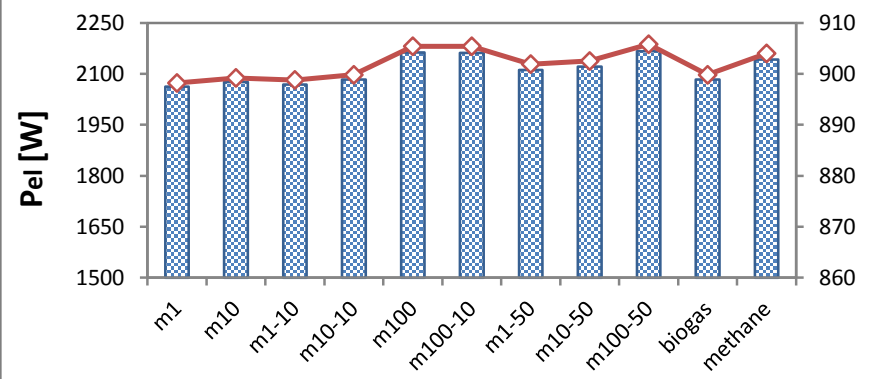

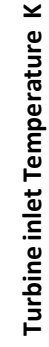

c)

Fuel type (Increasing LHV $\rightarrow$ )

Fuels $\quad \longrightarrow$ TIT

Fig.6 Electrical power output (Pel) against the fuel type and turbine inlet temperature. a) Fuels inlet temperature $150^{\circ} \mathrm{C}$. b) Fuels inlet temperature $400^{\circ} \mathrm{C}$. c) Fuels inlet temperature $750^{\circ} \mathrm{C}$. 


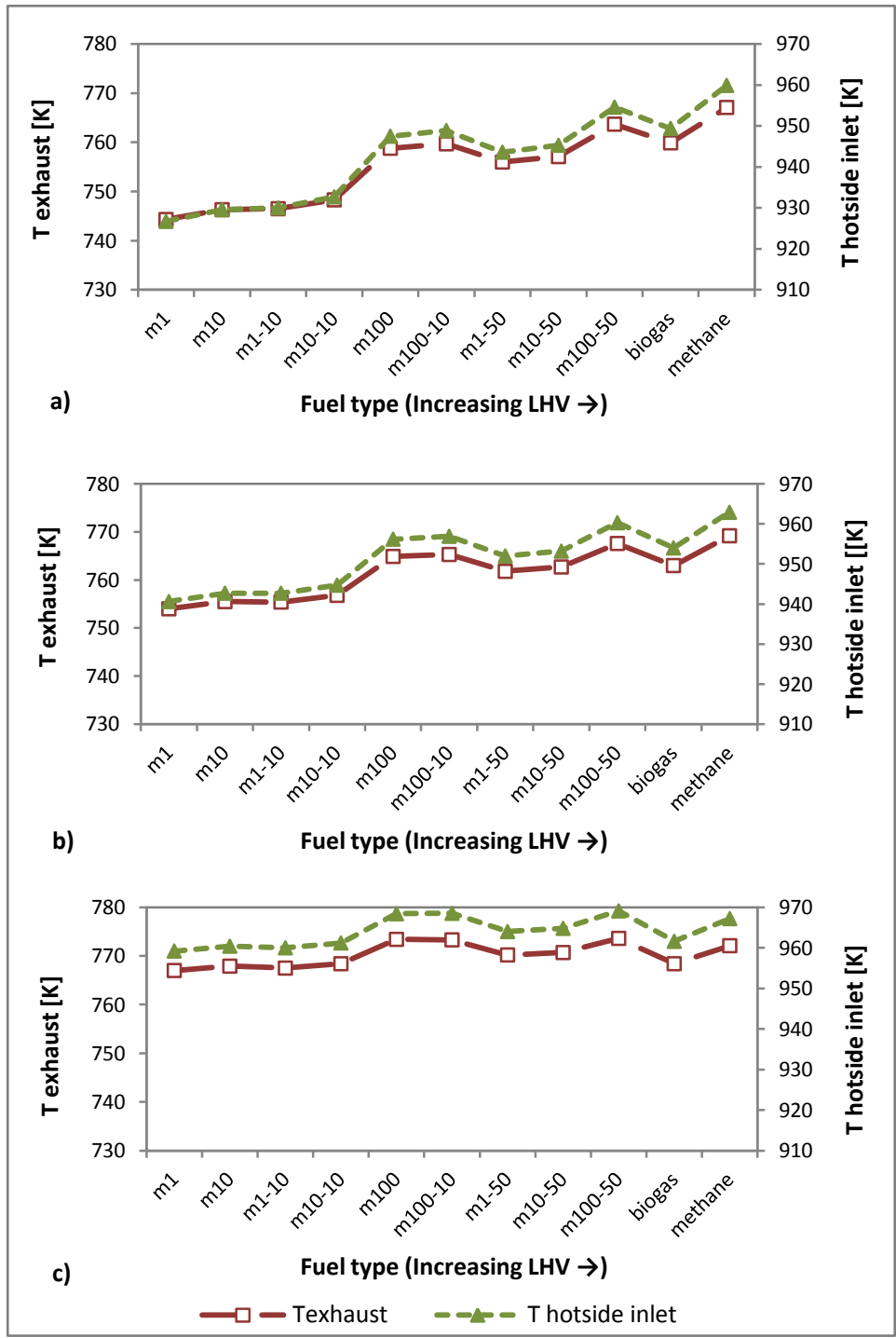

Fig. 7 Exhaust temperatures from the turbine and hot side inlet temperature to the heat exchanger for all the fuel types. a) Fuel inlet temperature $150^{\circ} \mathrm{Cb}$ ) Fuel inlet temperature $400^{\circ} \mathrm{C}$ c) Fuel inlet temperature $750^{\circ} \mathrm{C}$ 


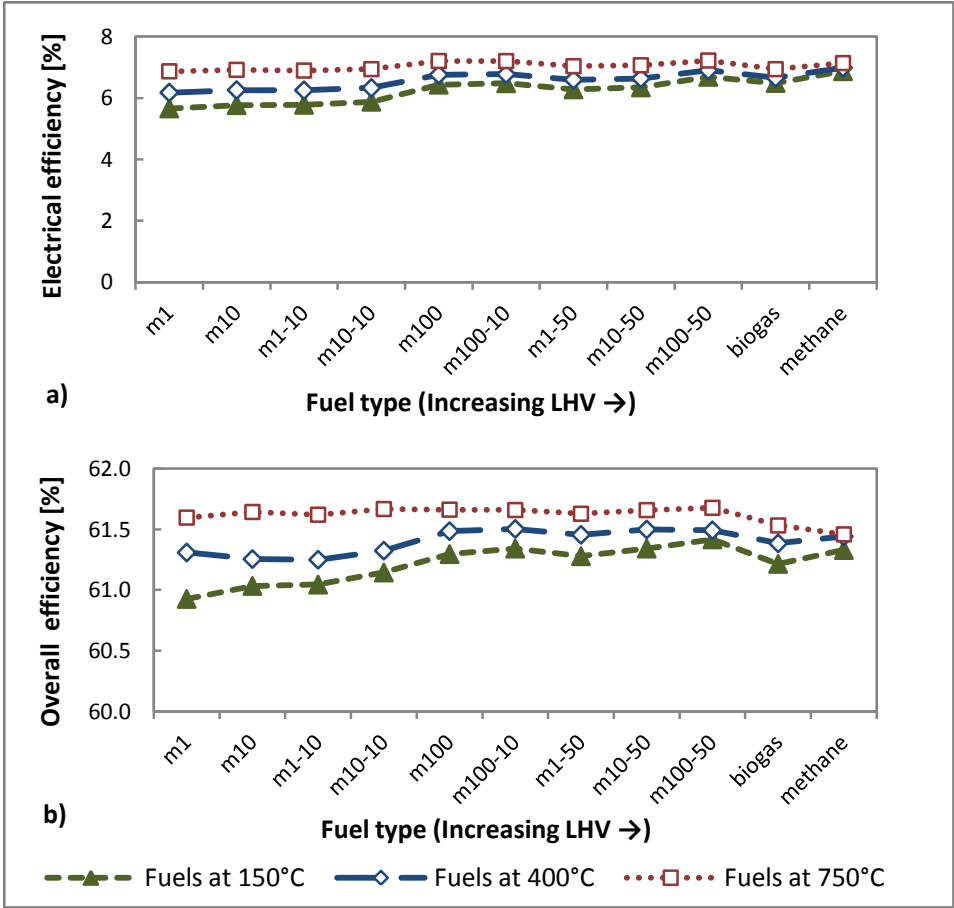

Fig. 8 Electrical and overall efficiency for $20 \%$ excess air 


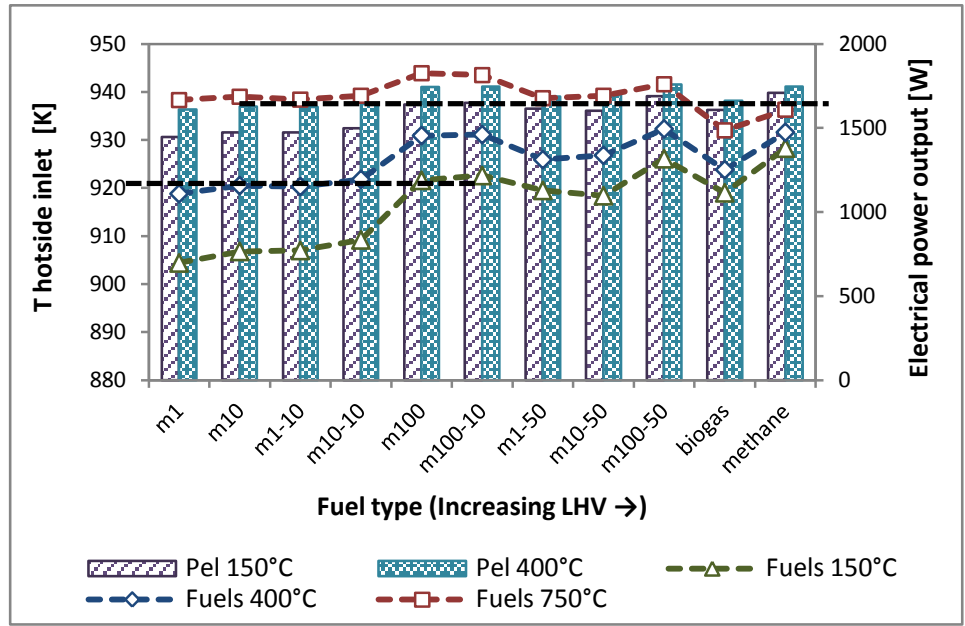

Fig. 9 Hot side inlet temperature to the heat exchanger and electrical power output for fuel inlet temperatures to the combustor of $150^{\circ} \mathrm{C}$ and $400^{\circ} \mathrm{C}$ with $43 \%$ excess air 


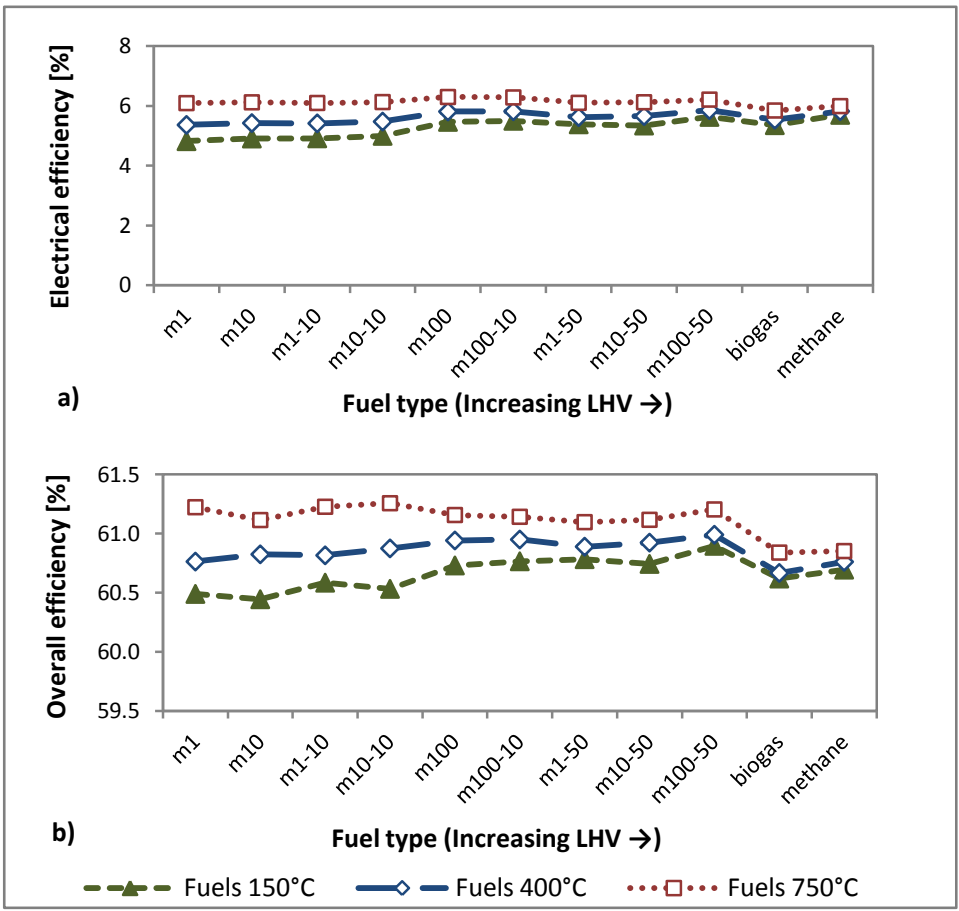

Fig. 10 Electrical and overall efficiencies for $43 \%$ excess air and operation of the heat exchanger up to $650^{\circ} \mathrm{C}$ 


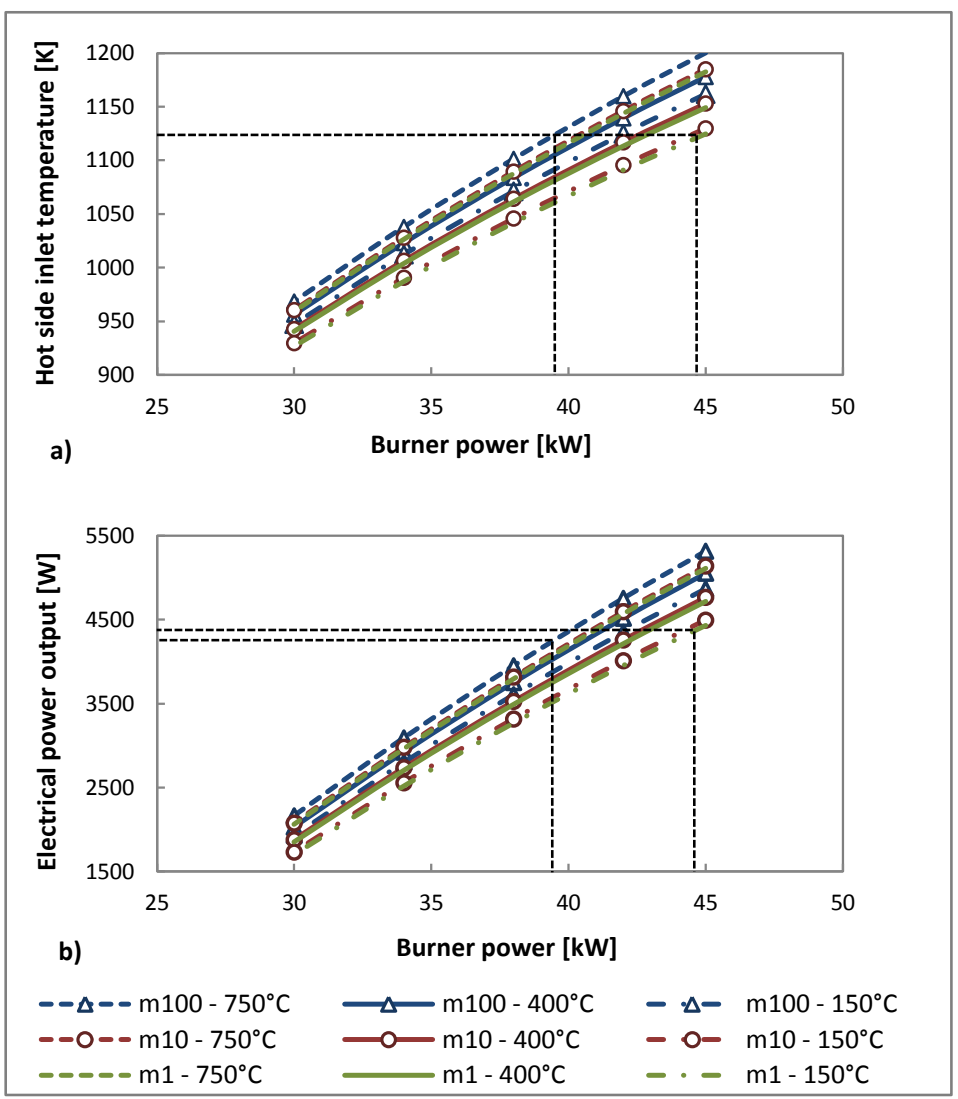

Fig. 11 Hot side inlet temperature to the heat exchanger and electrical power output against the burner power 


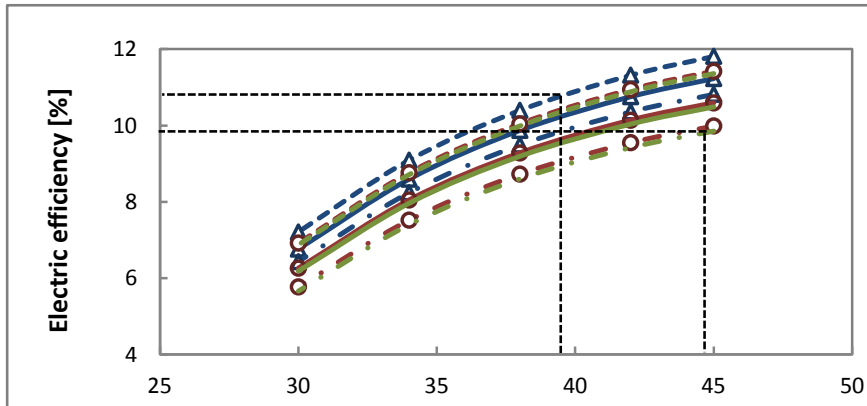

a)

Burner power [kW]

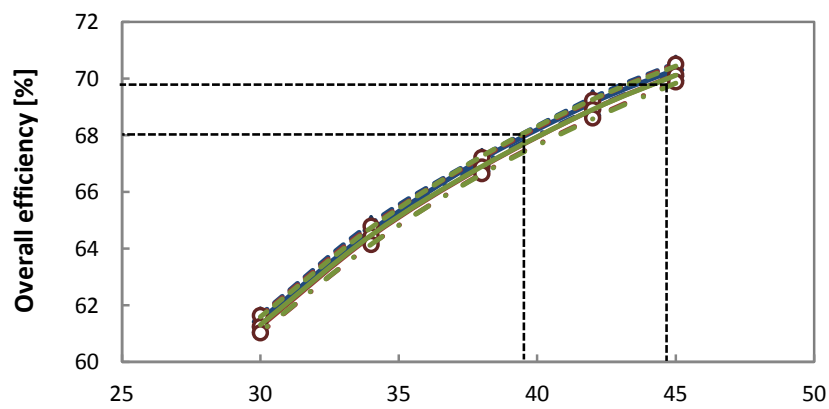

b)

Burner power $[\mathrm{kW}]$

$$
\begin{array}{lll}
--\Delta--\mathrm{m} 100-750^{\circ} \mathrm{C} & \square \mathrm{m} 100-400^{\circ} \mathrm{C} & -\Delta-\mathrm{m} 100-150^{\circ} \mathrm{C} \\
--\mathrm{O}--\mathrm{m} 10-750^{\circ} \mathrm{C} & \square \mathrm{m} 10-400^{\circ} \mathrm{C} & -\mathrm{O}-\mathrm{m} 10-150^{\circ} \mathrm{C} \\
----\mathrm{m} 1-750^{\circ} \mathrm{C} & -\mathrm{m} 1-400^{\circ} \mathrm{C} & --\mathrm{m} 1-150^{\circ} \mathrm{C}
\end{array}
$$

Fig. 12 Electrical and overall efficiency for $20 \%$ excess air and operation of the heat exchanger up to $850^{\circ} \mathrm{C}$ 


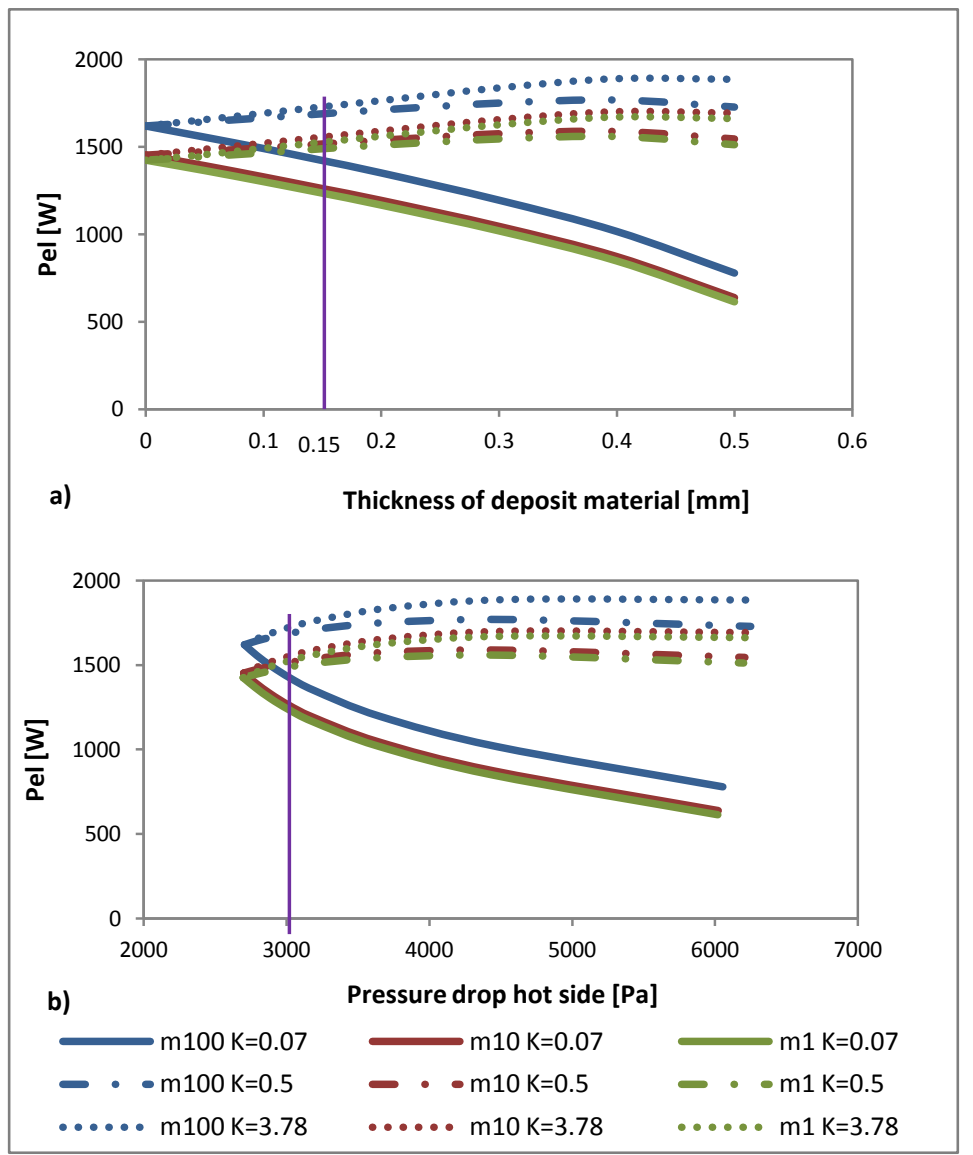

Fig. 13 Electrical power output versus thickness of deposit materials and pressure drop in the hot side of the heat exchanger 